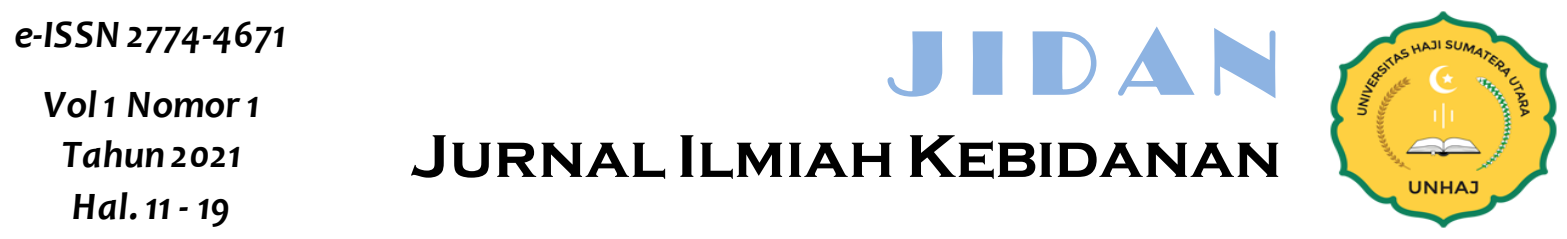

\title{
HUBUNGAN KONSUMSI MAKAN TINGGI ZAT BESI DENGAN ANEMIA PADA IBU HAMIL DI PUSKESMAS TUKKA
}

\author{
${ }^{1}$ Jenni Susi Sihite, S.Tr.Keb, MKM ${ }^{2}$ Tinawati Nainggolan, SKM, M.Kes \\ STIKes Nauli Husada Sibolga, Indonesia
}

\begin{abstract}
ABSTRAK
Angka kematian ibu yang tinggi masih menjadi masalah kesehatan di indonesia. Penyebab dari kematian ibu tersebut karena perdarahan yang disebabkan oleh anemia selama kehamilan. Penelitian ini bertujuan untuk mengetahui Hubungan Konsumsi Makan Tinggi Zat Besi Dengan Kejadian Anemia Pada Ibu Hamil Di Wilayah Kerja Puskesmas Tukka Kabupaten Tapanuli Tengah Tahun 2019. Jenis penelitian ini dengan menggunkan metode survey analitik dengan pendekatan cross sectional,. Penelitian dilaksanakan di PuskesmasTukka Kabipaten Tapanuli Tengah. Subjek penelitian adalah semua ibu hamil yang mempunyai usia kehamilan 8 minggu 24 minggu di PuskesmasTukka Kabipaten Tapanuli Tengah sebanyak 57 orang. Data dikumpul melalui kuesioner. Analisis data dilakukan dengan cara univariat, bivariat, dengan uji chi square. Berdasarkan hasil penelitian menunjukkan bahwa ibu hamil yang mengalami anemia sebanyak $37(64,9 \%)$ sedangkan ibu hamil yang tidak mengalami anemia sebanyak 20 (35,1\%). Hal ini menunjukkan hampir setengah dari semua ibu hamil menderita anemia. Hasil uji statistika didapatkan nilai $P$-value sebesar $0,000(>0,05)$. Secara statisk adanya hubungan yang signifikan antara kurang mengkonsumsi asupan zat besi dengan kejadian anemia pada ibu hamil di puskesmas tukka kabupaten tapanuli tengah tahun 2019. Puskesmas sebagai tempat pelayanan kesehatan terdekat dengan masyarakat perlu memberikan informasi pentingnya konsumsi makanan tinggi zat besi pada ibu hamil melalui kegiatan posyandu, ANC, kelas ibu hamil maupun kegiatan promosi kesehatan rutin dilaksanakan.
\end{abstract}

Kata Kunci : Konsumsi, ibu hamil, Tablet Fe

\section{ABSTRACT}

High maternal mortality is still a health problem in Indonesia. The cause of maternal death is due to bleeding caused by anemia during pregnancy. This study aims to see the relationship between high iron dietary consumption and the incidence of anemia in pregnant women in the work area of the Tukka Health Center, Tapanuli Tengah Regency in 2019. This type of research uses an analytical survey method with a cross sectional approach. The research was conducted at PuskesmasTukka Kabipaten Tapanuli Tengah. The subjects of the study were 57 pregnant women who were pregnant at 8 weeks - 24 weeks of pregnancy at PuskesmasTukka Kabipaten Tapanuli Tengah. Data collected through a questionnaire. Data analysis was carried out by univariate, bivariate, by means of the chi square test. Based on the results of the study, 37 (64.9\%) pregnant women who had anemia, while 20 (35.1\%) pregnant women who did not 
experience anemia. This shows that almost half of all pregnant women suffer from anemia. The results of statistical tests get a P-value of 0.000 (> 0.05). Statistically, there is a significant relationship between consuming less iron intake and the incidence of anemia in pregnant women at the Central Tapanuli District Health Center in 2019. Posyandu activities, ANC, pregnant women classes or routine health promotion activities are carried out.

Keyword: Consumption, pregnant woman, Fe Tablet

\section{PENDAHULUAN}

Anemia merupakan kondisi kadar hemoglobin dalam darah ibu hamil tidak mampu memenuhi kebutuhan oksigen yang dibutuhkan oleh tubuh. Standar untuk menetapkan anemia berbeda-beda antar kelompok, pada wanita usia subur $\mathrm{Hb}<12,0 \mathrm{~g} / \mathrm{dl}$ dikatakan anemia, sedangkan pada ibu hamil dikatakan anemia apabila $\mathrm{Hb}<11,0 \mathrm{~g} / \mathrm{dL}$ (Kemenkes RI, 2013).

Menurut World Health Organization (WHO), Kejadian anemia pada ibu hamil berkisar antara 20-89\% dengan menetapkan kadar Hb 11 gr\% sebagai dasarnya. Dinegara ASEAN angka kejadian anemia bervariasi, di Indonesia berkisar 70\%, di Filiphina berkisar 55\%, Thailand 45\%, Malaysia 30\%, dan Singapura 7\% yang menderita anemia. Kebanyakan anemia dalam kehamilan disebabkan oleh defisiensi zat besi dan perdarahan akut (WHO, 2015).

Riset Kesehatan Dasar (RISKESDAS) 2018 melaporkan secara nasional, proporsi anemia pada ibu hamil sebesar $48,9 \%$ dan angka ini mengalami peningkatan yang cukup tinggi dibandingkan dengan hasil RISKESDAS 2013 yaitu 37,1\% .

Anemia dapat terjadi akibat kekurangan zat gizi yang memiliki peran membentuk hemoglobin seperti zat besi, protein, piridoksin, vitamin B12, vitamin C, asam folat, dan vitamin E. Vitamin $\mathrm{C}$ berperan dalam absorbsi dan pelepasan zat besi dari transferin ke jaringan. Asam folat berfungsi dalam metabolisme asam amino yang dibutuhkan saat pembentukan sel darah merah dan sel darah putih. Vitamin B12 berfungsi untuk mengaktifkan asam folat, sedangkan vitamin E untuk stabilisasi sel (Setyawati dan Syauqy, 2015).

World Health Organization (WHO) mengatakan 40\% kematian ibu dinegara berkembang berkaitan dengan anemia pada kehamilan dan kebanyakan anemia pada kehamilan disebabkan oleh defisiensi besi dan perdarahan akut, bahkan tidak jarang keduanya saling berinteraksi. Badan Kesehatan Dunia melaporkan bahwa ibu-ibu hamil yang mengalami defisiensi besi sekitar $35-75 \%$ serta semakin meningkat seiring dengan pertambahan usia kehamilan. Hasil persalinan pada wanita hamil yang menderita anemia defisiensi besi adalah 12-28\% angka kematian janin, $30 \%$ kematian perinatal, dan 7- 10\% angka kematian neonatal (Misaroh, 2015).

Gizi ibu hamil perlu mendapat perhatian karena sangat berpengaruh pada perkembangan janin yang dikandungnya. Pada masa kehamilan gizi ibu hamil harus memenuhi kebutuhan gizi untuk dirinya dan untuk pertumbuhan serta perkembangan janin karena gizi janin tergantung pada gizi ibu, sehingga kebutuhan gizi ibu juga harus tetap terpenuhi. Asupan energi dan protein tidak mencukupi pada ibu hamil dapat menyebabkan Anemia. Wanita hamil yang mengalami Anemia jika Lingkar Lengan Atas (LLA) $<23,5 \mathrm{~cm}$. Ibu hamil dengan Anemia berisiko melahirkan Bayi Berat Lahir Rendah (BBLR) yang berpotensi mengalami kematian, gangguan pertumbuhan dan perkembangan anak. Anemia juga dapat menjadi penyebab tidak langsung kematian ibu (Kemenkes RI, 2016). 
Disumatra utara menunjukkan kenaikan anemia pada ibu hamil yaitu 33,03 \% tahun 2008, naik menjadi 53,09\% tahun 2010, dan menjadi 76,67 \% di tahun 2011 serta mengalami penurunan sedikit menjadi $75 \%$ ditahun 2012 dan tahun 2013 turun menjadi 68,85\%, angka ini masih jauh dari target yang di tentukan yaitu 80 \% ( Dinkes Propsu, 2014).

Di Indonesia diperkirakan setiap harinya terjadi 41 kasus anemia, dan 20 perempuan meninggal dunia karena kondisi tersebut. Tingginya angka ini disebabkan oleh rendah pengetahuan dan kesadaran akan bahaya anemia dalam kehamilan. anemia dalam kehamilan cenderung muncul pada pada kehamilan TM I dan III (Yuliatin, 2013).

Data yang diperoleh dari Puskesmas Tukka pada bulan Februari 2020 terdapat 57 orang ibu hamil yang melakukan ANC dari usia kehamilan 8 minggu - 24 minggu, $(28 \%)$ Ibu hamil dengan $\mathrm{HB}<11 \mathrm{gr} / \mathrm{d}$ l, dari survey awal peneliti lakukan dengan 6 orang ibu hamil di puskesmas Tukka didapatkan bahwa ada beberapa Ibu hamil kurang mengerti Asupan zat besi yang baik pada ibu hamil.

Berdasarkan latar belakang dan penelitian terkait diatas maka peneliti tertarik untuk melakukan penelitian yang berjudul "Hubungan Kurang Asupan Zat Besi Dengan Kejadian Anemia Pada Ibu Hamil Di Wilayah Kerja Puskesmas Tukka Kabupaten Tapanuli Tengah Tahun 2020".

\section{METODE PENELITIAN}

Jenis penelitian ini dengan menggunkan metode survey analitik dengan pendekatan cross sectional, yang bertujuan untuk mengetahui Hubungan Kurang Asupan Zat Besi Terhadap Kejadian Anemia Pada Ibu Hamil Di Wilayah Kerja Puskesmas Tukka Tahun 2020. Jenis penelitian ini merupakan wadah menjawab pertanyaan penelitian atau menguji kebenaran hipotesis (Sudigdo, 2013).

Tehnik pengambilan sampel dalam penelitian ini adalah total sampling. Seluruh populasi dijadikan sampel penelitian semuanya. Sampel yang di ambil dari peneliti ini adalah seluruh ibu hamil dengan usia kehamilan 8 minggu - 24 minggu yang memeriksakan dirinya ke puskesmas Tukka sebanyak 57 orang.

\section{HASIL DAN PEMBAHASAN}

4.1 Analisis Univariat

Analisis univariat dilakukan untuk melihat gambaran setiap variabel dalam penelitian. Adapun hasilnya sebagai berikut :

\subsubsection{Karakteristik Responden}

Berdasarkan data karakteristik responden didapatkan hasil distribusi frekuensi karakteristik umur dan pendidikan responden di Puskesmas Tukka Kabupaten Tapanuli tengah Tahun 2020 yang dapat dilihat pada tabel 4.1 berikut:

Tabel. 4.1. Distribusi Frekuensi Karakteristik Responden di Puskesmas Tukka Kabupaten Tapanuli Tengah Tahun 2020. 


\begin{tabular}{|c|c|c|c|}
\hline No & Karakteristik & $\mathbf{F}$ & $(\%)$ \\
\hline & Umur Ibu Hamil & & \\
\hline 1 & $<20$ tahun & 7 & 12,3 \\
\hline 2 & 20-30 tahun & 45 & 78,9 \\
\hline \multirow[t]{3}{*}{3} & $>30$ tahun & 5 & 8,8 \\
\hline & Total & 57 & 100,0 \\
\hline & Pendidikan Ibu Hamil & & \\
\hline 1 & Rendah (SD, SMP) & 7 & 12,3 \\
\hline 2 & Menengah (SMA) & 45 & 78,9 \\
\hline \multirow[t]{2}{*}{3} & Perguruan Tinggi (D-III, S1, S2) & 5 & 8,8 \\
\hline & Total & & 100,0 \\
\hline
\end{tabular}

Tabel 4.1 menunjukkan sebagaian besar ibu hamil berusia 20-30 tahun sebanyak 45 orang $(78,9 \%)$, dan sebagian kecil berusia $>30$ tahun. dan pendidikan ibu hamil sebagian besar berpendidikan menengah (SMA) yaitu sebanyak 45 orang $(78,9 \%)$ dan sebagian kecil perguruan tinggi sebanyak $5(8,8 \%)$.

\subsubsection{Anemia Pada Ibu Hamil}

Tabel 4.2 Distribusi frekuensi berdasarkan kejadian anemia pada ibu hamil di puskesmas tukka kabupaten tapanuli tengah tahun 2020

\begin{tabular}{lcll}
\hline No & $\begin{array}{l}\text { Anemia pada ibu } \\
\text { hamil }\end{array}$ & $\begin{array}{l}\text { Frekuensi } \\
\text { (n) }\end{array}$ & $\mathbf{\%}$ \\
\hline 1 & Anemia & 37 & 64,9 \\
2 & Tidak anemia & 20 & 35,1 \\
\hline & Total & $\mathbf{5 7}$ & $\mathbf{1 0 0 , 0}$ \\
\hline
\end{tabular}

Berdasarkan tabel 4.2 dapat diketahui bahwa sebagian besar responden ibu hamil yang mengalami anemia sebanyak 37 responden $(64,9 \%)$, Sebagian kecil responden ibu hamil tidak mengalami anemia yaitu sebanyak 20 responden $(35,1 \%)$.

Tabel 4.3 Distribusi frekuensi berdasarkan asupan zat besi pada ibu hamil di puskesmas tukka kabupaten tapanuli tengah tahun 2020.

\begin{tabular}{lcll}
\hline No & Pengetahuan & $\begin{array}{l}\text { Frekuensi } \\
\text { (n) }\end{array}$ & \% \\
\hline 1 & Tidak konsumsi & 35 & 61,4 \\
2 & Konsumsi & 22 & 38,6 \\
\hline & Total & $\mathbf{5 7}$ & $\mathbf{1 0 0 , 0}$ \\
\hline
\end{tabular}

Berdasarkan tabel 4.3 dapat diketahui bahwa sebagian besar responden mengkonsumsi asupan zat besi pada ibu hamil yaitu tidak mengkonsumsi zat besi pada ibu hamil sebanyak 35 responden $(61,4 \%)$, Sebagian kecil responden mengkonsumsi zat besi pada ibu hamil yaitu sebanyak 22 responden $(38,6 \%)$.

\subsection{Analisis Bivariat}

Analisis bivariat dalam penelitian dilakukan untuk mengetahui hubungan antara variabel indepeden yaitu kurang asupan zat besi pada ibu hamil variabel dependen yaitu kejadian anemia pada ibu hamil dengan menggunakan uji chi-square, hasil analisis tersebut sebagai berikut:

4.2 Hubungan asupan zat besi dengan kejadian anemia pada ibu hamil di puskesmas tukka kabupaten tapanuli tengah tahun 2020 


\begin{tabular}{|c|c|c|c|c|c|c|c|}
\hline \multirow{3}{*}{ Asupan Zat Besi } & \multicolumn{4}{|c|}{$\begin{array}{l}\text { Kejadian anemia pada ibu } \\
\text { hamil }\end{array}$} & \multirow{2}{*}{ Total } & & \multirow{3}{*}{ p value } \\
\hline & \multicolumn{2}{|c|}{ Anemia } & \multicolumn{2}{|c|}{$\begin{array}{l}\text { Tidak } \\
\text { Anemia }\end{array}$} & & & \\
\hline & $\mathbf{n}$ & $\%$ & $\mathbf{n}$ & $\%$ & $\bar{n}$ & $\%$ & \\
\hline Tidak Konsumsi & 34 & 91,9 & 1 & 5 & 35 & 61,4 & \\
\hline Konsumsi & 3 & 8,1 & 19 & 95 & 22 & 38,6 & 0,000 \\
\hline Total & 37 & 100 & 20 & 100 & 57 & 100 & \\
\hline
\end{tabular}

Berdasarkan Tabel 4.3 menunjukkan bahwa dari 35 ibu hamil tidak konsumsi asupan zat besi yaitu sebanyak $34(91,9)$ diantaranya mengalami anemia, sedangkan dari 22 ibu hamil yang mengkonsumsi zat besi $3(8,1)$ diantaranya mengalami anemia.

Hasil uji statistika didapatkan nilai $P$-value sebesar 0,000 (>0,05). Secara statisk adanya hubungan yang signifikan antara kurang mengkonsumsi asupan zat besi dengan kejadian anemia pada ibu hamil di puskesmas tukka kabupaten tapanuli tengah tahun 2020.

Berdasarkan hasil penelitian menunjukkan bahwa ibu hamil yang mengalami anemia sebanyak 37 (64,9\%) sedangkan ibu hamil yang tidak mengalami anemia sebanyak 20 (35,1\%). Hal ini menunjukkan hampir setengah dari semua ibu hamil menderita anemia. Maturasi sel darah merah bergantung pada jumlah zat-zat makanan yang adekuat seperti B12, asam folat, dan zat besi.

(Chatherine 2012) pada ibu hamil memiliki ketidak adekuatan nutrisi dalam tubuhnya. Selain itu, hemodilusi yang dialami ibu hamil dapat menyebabkan penurunan konsentrasi hemoglobin. Maturasi sel darah merah yang terhambat dan kuantitas homoglobin yang kurang menempatkan ibu hamil pada kondisi anemia.

Handayani (2008) menyatakan bahwa tingkat pendidikan yang dicapai seseorang mempunyai hubungan nyata dengan pengetahuan gizi dari makanan yang dikonsumsinya. Pengetahuan gizi dan kesehatan merupakan salah satu jenis pengetahuan yang dapat diperoleh melalui pendidikan. Pengetahuan gizi dan kesehatan akan berpengaruh terhadap pola konsumsi pangan. Semakin banyak pengetahuan tentang gizi dan kesehatan, maka semakin beragam pula jenis makanan yang dikonsumsi sehingga dapat memenuhi kecukupan gizi dan mempertahankan kesehatan individu (suhardjo, 1992).

Hasil penelitian didapatkan lebih dari setengah responden masih mengalami anemia pada ibu hamil. Ini salah satu masalah meningkatkan angka kematian ibu dan anak. Menganjurkan ibu untuk rajin menkonsumsi obat yang sudah diberikan oleh tenaga kesehatan seperti B6 B12 dan asam folat $1 \mathrm{x} 1$. Menggunakan air putih secara teratur dan menganjurkan ibu untuk makanmakana yang berpariasi dan cukup mengandung kalori seperti nasi, ubi, kentang dan protein seperti daging, ikan, telor, kacang-kacangan dan susu setiap hari dengan menerapkan porsi kecil tapi sering untuk menanggulangi terjadinya anemia.

Menganjurkan ibu untuk mengurangi konsumsi teh terutama sesaat setelahbmakan karena teh akan menghambat proses penyerapan zat besi yang terdapat dalam makanan. Ibu tetap bisa mengkonsumsi teh setelah makan yaitu dengan jarak 2 jam setelah makan. Minum teh saat masih hangat. Karena saat teh sudah dingin manfaat teh akan hilang.

\section{Asupan Zat Besi Pada Ibu Hamil}

Responden yang mengalami anemai dapat diketahui bahwa berdasarkan responden mengkonsumsi asupan zat besi pada ibu hamil yaitu tidak mengkonsumsi zat besi pada ibu hamil sebanyak 35 responden $(61,4 \%)$, dan responden mengkonsumsi zat besi pada ibu hamil yaitu sebanyak 22 responden $(38,6 \%)$. Dari hasil uji statistik menunjukkan adanya hubungan antara asupan zat besi dengan kejadian anemia pada ibu hamil, 
Menurut winarno (1997). Tingkat ekonomi (pendapatan) yang rendah dapat mempengaruhi pola makan. Pada tingkat pendapatan yang rendah, sebagian besar pengeluaran ditujukan untuk memenuhi kebutuhan pangan dengan berorientasi pada jenis pangan karbohidrat. Hal ini disebabkan makanan yang mengandung banyak karbohidrat lebih mudah dibandingkan dengan makanan sumber zat besi, sehingga kebutuhan zat besi akan sulit terpenuhi, dan dapat berdampak pada terjadinya anemia gizi besi.

Distribusi frekuensi gambaran tentang kurang asupan zat besi didapat hasil sebagian besar responden mengalami anemia sebanyak 37 responden $(64,9 \%)$. Petugas kesehatan mempunyai peran yang sangat penting untuk meningkatkan asupan zat besi pada ibu hamil yaitu dengan cara memberikan pelayanan kepada masyarakat sesuai dengan kebutuhannya, seperti pada saat kunjungan Antental Care pada ibu hamil selain dilakukan pemeriksaan diberikan juga penyuluhan tentang pentingnya mengkonsumsi asupan zat besi pada masa kehamilan untuk mencegah terjadinya anemia pada ibu hamil.

Tujuan mengkonsumsi zat besi yaitu untuk mencegah terjadinya anemia apabila ibu hamil mengalami anemia dapat menyebabkan meningkatnya risiko keguguran, prematuritas, atau berat bayi lahir rendah (BBLR). Faktor yang memengaruhi responden mengkonsumsi asupan zat besi yaitu perilaku petugas kesehatan dimana dapat lebih ditingkatkan apabila petugas kesehatan mampu memberikan penyuluhan yang seoptimal mungkin terutama tentang pentingnya mengonsumsi asupan zat besi pada ibu hamil untuk menjaga kesehatan diri sendiri dan janin yang dikandung (Lestari, 2017).

Hasil penelitian menunjukkan bahwa ibu hamil yang mengkonsumsi asupan zat besih masih rendah di wilayah kerja Puskesmas Tukka kabupaten tapanuli tengah yang masih tergolong rendah dapat disebabkan karena masih banyak ibu hamil yang belum mengerti bagaimana asupan makanan yang mengandung tinggi zat besi pada kehamilan, mengenai asupan zat besi. Akibatnya, kesadaran ibu hamil untuk mengkonsumsi asupan zat besi juga masih rendah. Hal ini yang menjadi salah satu penyebab masih meningkatnya angka kejadian anemia. Pentingnya informasi mengenai kebutuhan asupan zat besi pada ibu hamil, manfaat zat besi, sumber makanan yang mengandung zat besi, akibat yang ditimbulkan apabila kekurangan asupan zat besi, dan informasi lainnya dapat diperoleh ibu melalui penyuluhan yang diberikan petugas kesehatan dalam kunjungan ANC. Oleh karena itu, pengetahuan ibu hamil tentang kurang asupan zat besi perlu ditingkatkan lagi dengan cara meningkatkan upaya promosi kesehatan kepada ibu hamil mengenaia pola asupan zat besi misalnya dengan penyuluhan dan pemberian informasi melalui pamphlet, stiker dan media komunikasi lainnya

\section{Hubungan kurang asupan zat besi dengan kejadian anemia pada ibu hamil}

Asupan zat besi dengan kejadian anemia menunjukkan bahwa dari 35 ibu hamil tidak konsumsi asupan zat besi yaitu sebanyak $34(91,9)$ diantaranya mengalami anemia, sedangkan dari 22 ibu hamil yang mengkonsumsi zat besi $3(8,1)$ diantaranya mengalami anemia.

Hasil uji statistika didapatkan nilai $P$-value sebesar 0,000 (>0,05). Secara statisk adanya hubungan yang signifikan antara kurang mengkonsumsi asupan zat besi dengan kejadian anemia pada ibu hamil di puskesmas tukka kabupaten tapanuli tengah tahun 2020.

Frekuensi konsumsi makanan sumber zat besi dapat mempengaruhi kondisi kesehatan ibu hamil terutama janin yang dikandungnya. Janin membutuhkan makanan yang cukup untuk proses perkembangan serta pertumbuhan selama didalam perut ibunya. Jika kebutuhan sumber zat besi selama kehamilan tidak terpenuhi maka dikhawatirkan akan terjadi keguguran, bayi lahir dengan berat badan rendah, terjadinya sebelum dan sewaktu melahirkan serta dampak terburuknya adalah kematian ibu (wara,2006) 
Kebijakan pemerintah adalah memberikan tablet zat besi $320 \mathrm{mg}$ dan asam folat $0,5 \mathrm{mg}$ untuk semua ibu hamil sebanyak satu kali satu tablet selama 90 hari. Diperkirakan jumlah tersebut mencukupi kebutuhan tambahan zat besi selama kehamilan yaitu $1000 \mathrm{mg}$ di samping yang berasal dari makanan.

Hasil penelitian ini juga sejalan dengan penelitian terdahulu oleh Kautsar (2014) bahwa ada hubungan antara peran petugas kesehatan dengan kepatuhan konsumsi tablet $\mathrm{Fe}(\mathrm{p}=0.028<$ 0.05). Hal ini menunjukkan bahwa terdapat kecenderungan ibu yang patuh dalam mengonsumsi tablet $\mathrm{Fe}$ karena adanya peran dari petugas kesehatan. Perilaku petugas kesehatan pada responden sangat mempengaruhi kepatuhan dalam mengkonsumsi tablet besi karena petugas kesehatan selalu memberi motivasi untuk mengonsumsi tablet besi sampai habis.

Hasil penelitian ini sejalan dengan penelitian Kenang, dkk. (2018) yang menunjukan bahwa peran petugas kesehatan yang baik dapat mempengaruhi kepatuhan ibu hamil didalam mengkonsumsi tablet besi ( $\mathrm{Fe}$ ) bila dibandingkan peran petugas kesehatan kurang baik. Hasil analisis membuktikan adanya hubungan yang signifikan petugas kesehatan dengan kepatuhan ibu hamil dalam mengkonsumsi tablet besi $(\mathrm{Fe})$ dengan nilai $p=0,005(p<0,05)$. Agar ibu hamil bisa patuh diperlukan peran petugas kesehatan, perlu ditingkatkan pelayanannya seperti dengan cara petugas kesehatan memberikan atau menginformasikan pentingnya tablet besi, bahaya anemia dan menganjurkan agar ibu hamil meminum tablet besi (Fe) dengan baik sdan teratur, contohnya dengan rutin memberikan penyuluhan.

Hasil penelitian menunjukkan bahwa sebagian besar ibu hamil yang mengalami anemia dan berpengaruh terhadap rendahnya mengkonsumsi asupan zat besi pada ibu hamil di wilayah kerja Puskesmas Tukka kabupaten tapanuli tengah kesadaran ibu hamil untuk mengkonsumsi asupan zat besi juga masih rendah. Hal ini yang menjadi salah satu penyebab masih meningkatnya angka kejadian anemia. Kebutuhan zat besi ibu hamil meningkat pada kehamilan trimester II dan III. Pada masa tersebut kebutuhan zat besi tidak dapat diandalkan dari Tablet zat besi saja. Walaupun sudah mengkonsumsi tablet zat besi sebanyak 90 tablet sangat penting juga menu harian makanan yang mengandung zat besi karna zat besi sangat penting bagi ibu hamil supaya tidak anemia dan tidak terjadi perdarahan setelah melahirkan, bahkan infeksi, kematian janin intrauteri, cacat bawaan dan abortus.

\section{KESIMPULAN}

Berdasarkan hasil penelitian didapat beberapa kesimpulan antara lain :

1. Subjek penilaian ini dapat diketahui bahwa sebagian besar responden ibu hamil yang mengalami anemia sebanyak 37 responden $(64,9 \%)$, Sebagian besar responden ibu hamil tidak mengalami anemia yaitu sebanyak 20 responden $(35,1 \%)$.

2. Subjek penilaian ini dapat diketahui bahwa sebagian besar responden mengkonsumsi asupan zat besi pada ibu hamil yaitu tidak mengkonsumsi zat besi pada ibu hamil sebanyak 35 responden $(61,4 \%)$, Sebagian besar responden mengkonsumsi zat besi pada ibu hamil yaitu sebanyak 22 responden $(38,6 \%)$.

3. Ada hubungan yang bermakna antara kurang asupan zat besi dengan kejadian anemia pada ibu hamil p-value 0,000

\section{SARAN}

Saran yang dikemukakan berdasarkan kesimpulan penelitian diatas sebagai berikut:

1. Bagi Puskesmas Tukka Kabupaten Tapanuli Tengah

Untuk setiap pelayanan kesehatan yang terdapat di PuskesmasTukka mengadakan penyuluhan kesehatan kepada masyarakat khususnya ibu hamil yang berkaitan dengan status gizi bagi ibu 
hamil, asupan zat besi bagi ibu hamil dan lain-lain sehingga ibu hamil mempunyai pengetahuan yang luas.

2. Petugas kesehatan

Petugas kesehatan sebaiknya lebih peduli pada ibu hamil, dan selalu mengadakan penyuluhan setiap ada posyandu. Petugas kesehatan seharusnya selalu memberikan dukungan pada ibu hamil yang memeriksakan kehamilannya untuk mengkonsumsitinggi zat besi,

3. Ibu hamil

Ibu hamil hendaknya secara aktif meningkatkan pengetahuan terkait pentingnya asupan zat besi selama masa kehamilan sehingga dapat lebih patuh mengkonsumsi tinggi zat besi agar terhindar dari anemia selama kehamilan.

4. Bagi instansi pendidikan

Diharapkan Institusi Pendidikan hendaknya lebih meningkatkan lagi pembelajaran mengenai peran asuhan kehamilan tentang konsumsi tinggi zat besi pada ibu hamil dalam hal komunikasi, motivasi, fasilitasi dan konsultasi sehingga peran tenaga kesehatan dalam hal preventif dapat lebih ditingkatkan, tidak hanya mendalami teori tetapi juga dalam hal praktek.

5. Bagi peneliti selanjutnya

Peneliti selanjutnya diharapkan melakukan penelitian yang terkait peran tenaga kesehatan terhadap asupan zat besi pada ibu hamil dengan responden penelitian yang lebih banyak, sehingga hasil penelitian akan lebih akurat. Peneliti selanjutnya sebaiknya mengendalikan pendidikan ibu hamil di dalam penelitian sehingga dapat mengkaji hal-hal yang belum dapat dimunculkan atau belum dibahas dalam penelitian ini.

\section{DAFTAR PUSTAKA}

Anasta, Prita Yulianti, Muhammad Basyuni dan Indra Lesmana. 2013. "Skrining Fitokimia Metabolit Sekunder pada Daun Binahong (Anredera cordifolia (Ten.) Steenis) untuk Uji In Vitro Daya Hambat Pertumbuhan Aeromonas hydrophila". Fakultas Matematika dan Ilmu Pengetahuan Alam, Universitas Sumatera Utara. Jurnal.

Alimul Hidayat, A Aziz. 2007. Metode Penelitin Keperawatan dan Teknik Analisis Data. Jakarta: Salemba Medika

Available from: http://ejournal.litbang.depkes.go.id/index.php/kespro/article/viewFile/5438/ 4474

Bothamley, Judi dan Boyle M. Patofisiologi dalam Kebidanan. Jakarta: Penerbit Buku Kedokteran EGC; 2012.

Cunningham F, Al G et. Obstetri Williams. 21 Vol.2. Jakarta: EGC; 2006.

Citrakesumasari. Anemia Gizi, Masalah dan Pencegahannya. Yogyakarta: Kalika; 2012.

Dinas Kesehatan Provinsi Sumatera Utara. 2014. Profil Kesehatan Provinsi Sumatera Utara Tahun 2014. Medan.

Kementerian Kesehatan RI. 2016. INFODATIN Pusat Data dan Informasi Kementerian Kesehatan RI Situasi Balita Pendek. Jakarta Selatan 
Mahmudah U, Cahyati WH, Wahyuningsih AS. Jurnal Kesehatan Masyarakat. J Kesehat Masyarakat. 2013;8(2):113-20.

Masthalina H, Laraeni Y, Dahlia Putri Y. Pola Konsumsi (Faktor Inhibitor Dan Enhancer Fe) Terhadap Status Anemia. J Kesehat Masy, 2015

Manuaba IB. Ilmu Kebidanan, Penyakit Kandungan dan Keluara Berencana. Jakarta: EGC; 2012

Manuaba, IAC., I Bagus, dan IB Gde. 2012. Ilmu Kebidanan, Penyakit Kandungan dan KB untuk Pendidikan Bidan. Edisi kedua. Jakarta: EGC

Pala K, Dundar N. Prevalence \& risk factors of anaemia among women of reproductive age in Bursa, Turkey. Indian J Med Res. 2008;(128):282-6.

Riset Kesehatan Dasar (Riskesdas) (2018). Badan Penelitian dan Pengembangan Kesehatan Kementerian RI tahun 2018.

Sugiyono. 2013. Metode Penelitian Pendidikan Pendekatan Kuantitatif, Kualitatif, dan R\&D. Bandung: Alfabeta.

Syafrudin. 2011. Penyuluhan Kesehatan Pada Remaja, Keluarga, Lansia dan Masyarakat. Jakarta: Trans Info Media.

Studi P, Gizi I, Kedokteran F, Diponegoro U. of Nutrition College , Volume of Nutrition College, Volume Tahun 2014 Online di: http://ejournals1.undip.ac.id/index.php/jnc Journal of Nutrition College , Volume 3 , Nomor 4 , Tahun 2014. 2014;4:903-10.

Sudikno, Sandjaja. Prevalensi dan Faktor Risiko Anemia pada Wanita Usia Subur di Rumah Tangga Miskin di Kabupaten Tasikmalaya dan Ciamis, Provisi Jawa Barat. J Kesehat Reproduksi [Internet]. 2016;7(April):71-82.

Supariasa, Nyoman ID, Bakri B, Fajar I. Penelitian Status Gizi. Jakarta: EGC; 2012.

Varney H, Kriebs JM, Gegor LC. Buku Ajar Asuhan Kebidanan. 4 Vol.1. Jakarta: EGC; 2007.

Winkjosastro H, Saifuddin A, T R. Ilmu Kebidanan. 3 Cetakan. Jakarta: Yayasan Bina Pustaka Sarwono Prawirohard jo; 2005.

WHO. World Health Statistic Report 2015. Geneva: World Health Organization; 2015. 